УДК 821.163.41(091)-94.09

https://doi.org/10.18485/msc50.2019.1.ch29

Љиљана Јухас Георгиевска

\title{
БИБЛИЈСКЕ ПАРАЛЕЛЕ У ФУНКЦИЈИ ГРАЪЕЊА ЈУНАКА У ДОМЕНТИЈАНОВОМ „ЖИВОТУ СВЕТОГ САВЕ”
}

1.

Међу делима српске житијне литературе Живот светог Саве од јеромонаха Доментијана (довршен 1242/43. или 1253/54. године) издваја се сложеношћу књижевно-уметничке структуре и богатством значења. Његове карактеристике јесу документарност у високом степену и снажна симболизација којом се реални слој преводи у митски и надреални. Законитости поетике овог жанра, већ по себи, писце усмеравају ка дограђивању, модификацији и ирационализацији историјско-документарног слоја, у сврху типизације јунака. Доментијан је још консеквентнији у овоме; код њега се заправо остварују врхунске и крајње могућности оваквог процеса. Сликајући светог Саву, конкретне јунакове индивидуалне људске карактеристике надилази елементима космичке симболизације, истицањем лепоте божанске вечности. Како је то већ запажено, полази од поставки естетике небеског царства и потенцира предодређеност свог јунака за несвакидашње дело/подвиг; ${ }^{1}$ отуда историјско-документарни план веома често преводи и уздиже у митско-библијске алегорије, симболе. Свети Сава у делу израста у лик-функцију. Његова осећања потчињена су космичким и божанским идеалима а делање се одвија према Божјем промислу и одређеном плану; сви догађаји, чак и они који су презентовани без посебне назнаке да узводе ка вишем циљу, имају такав семантизам и усаглашени су са општим контекстом дела и основном идејом писца о јунаку/јунацима.

Отуда је разумљиво што писац оваквог опредељења користи, и то веома интензивно и разнолико, управо библијске садржаје као једно од

${ }^{1}$ Види: Милорад Лазић, Естетика царства небеског у Доментијановим житијима. Зборник Српска Византија. Приредио Бојан Јовановић, Београд, 1993, стр. 131-142. 
основних средстава портретизације јунака, остваривања целокупне атмосфере дела и његових значења.

Поред бројних паралела, у Животу светог Саве постоје асоцијације, цитати (њих 269 а то није и коначан број) и др. ${ }^{2}$ И сам пишчев исказ носи трагове ослањања на библијску, нарочито псаламску фразу. На семантичком плану описи Савиних путовања у Света Места изразито су погодни за додатно обогаћивање уметничке визије; дотицаји са библијским садржајима су веома интензивни и вишеструки, што захтева озбиљно и дубинско истраживање структуре дела. Овом приликом испитиваћемо функцију библијских паралела у грађењу лика главног јунака.

Сваки од поменутих видова коришћења Светог Писма изискује посебну и темељну анализу.

2.

Упоређивање јунака са истакнутим личностима Старог и Новог завета опробано је средство житијне литературе. У српској књижевности оно се примењује од првих дела овог жанра. Свети Сава у свом Животу светог Симеона свога јунака компарира са Аврамом, Соломоном, Давидом, Исаком, Јаковом, Јосифом и др. ${ }^{3}$ Патријарху Авраму (по Библији оснивачу јеврејског народа) Немања је раван по своме милосрђу. Представа о Авраму гостољупцу (у свој дом прима три незнанца) према Кюизи постағь (18,1-15), шире је схваћена како би овај библијски јунак постао пишчев ослонац у дефинисању важне Немањине врлине. Компарација Немање са царевима Соломоном и Давидом и патријархом Јосифом изведена је у сегменту којим се довршава приповедање о Немањиној владавини; она служи утврђивању основних јунакових владарских и људских врлина (поседовао је Соломонову премудрост, Давидову кротост и Јосифову добру нарав). ${ }^{4}$ Премудрост свога јунака писац ће и конкретно

2 Подаци према књизи: Св. Писмо у нашим старим споменицима. Издали Станоје Станојевић и др Душан Глумац. Српска Краљевска Академија, Београд, 1932 (СКА, Посебна издања, књига LXXXIX, Друштвени и историјски списи, књига 39). Преглед идентификованих цитата из Доментијановог Живота светог Саве ту се даје на стр. 136-213.

3 Живот Стебана Немане (Св. Симеона) од Св. Саве (превод Миливоја Башића), у књизи Стара српска книжевност, 1. Предговор, избор и редакција др Драгољуб Павловић, Матица српска - Српска књижевна задруга, Нови Сад - Београд, 1966, стр. 27-47.

4 Исто, стр. 31. 
демонстрирати у поукама, које држи синовима Стефану и Вукану поводом своје абдикације, и Сави, пред своју смрт. Оне су, већим делом, саздане из навода из Прича Соломонових; овим путем Немања се заправо и сам идентификује са чувеним библијским царем. Тиме је обезбеђена подударност између пишчевог и јунаковог гледишта, на чему овај писац и другде инсистира. Занимљиве су и друге паралеле, нпр. идентификација Немање са Исаком (моменат благосиљања наследника). Са Јосифом је најпре упоређен Сава а касније оба његова брата (Јосиф узима из Египта тело свога оца Јакова и преноси га у домовину, а Стефан и Вукан дочекују Немањино тело које Сава доноси из Хиландара, сами га носе и са великом чашћу полажу у гроб у Студеници). Осим у случају са Соломоном, библијске паралеле имају важност у оквиру одређених сегмената дела и локализовану функцију. Детерминишу, пре свега, моралне и људске особине; важне су и за утврђивање карактера односа међу јунацима који су у најближем сродству.

Стефан Првовенчани придаје наглашенији значај паралелама. ${ }^{5} \mathrm{y}$ првим поглављима дела свог јунака пореди са првим људима, Адамом и Евом; компарација је занимљива јер није наглашена; открива се тек сучељавањем увода (његова централна тема је божје милосрђе према грешном људском роду) и почетних глава биографије. На једној страни, показује се да се у слици Немањиног живота понавља историја људског рода (у Немањиној младости обнављају се догађаји који су се десили у младости људског рода) а на другој се он, насупрот првим људима, непрекидно и успешно супротставља ђаволу, личним ставом и заштићен Христом. ${ }^{6}$ Развијена је и паралела са Јосифом, у делу текста у коме се говори о Немањином страдању од браће. Писац поред сродности установљава и различитости. Оне су у домену Божје наклоности према њима. Иако обојицу избавља из заточења, Немању више награђује (поставља га за владара). Он поседује и већи број врлина од Јосифа. У моменту када предузме акцију да би казнио јеретике, Немања је компариран са про-

${ }^{5}$ Стефан Првовенчани, Живот светог Симеона. У књизи: Стефан Првовенчани, Сабрани списи. Приредила мр Љиљана Јухас-Георгиевска. Просвета - СКЗ, Београд, 1988, стр. 63-101. (Библиотека: Стара српска књижевност у 24 књиге, књига трећа). Ту је објављен Башићев превод овог дела, а у редакцији Љ. Јухас-Георгиевске.

${ }^{6}$ О овом питању подробније у нашем раду Стефан Првовенчани и юегово дело, штампаном као предговор књизи: Стефан Првовенчани, Сабрани списи, на стр. 9-50. 
роком Илијом који је „устао на бестидне јереје”. Када надвлада своје непријатеље, према Првовенчаном, раван је Мојсију (у ситуацији када овај побеђује Амаличане); необично је то што је старозаветном библијском јунаку приписана победа уз помоћ крста јер крст је симбол хришћанства, дакле Новог завета. Главни јунак и његова супруга Ана, у тренуцима туге за одбеглим сином Растком, упоређују се са Јовом. Они се питају да ли ће се на њима збити искушења Јовова, тј. да ли ће их Бог искушавати као што је у прошлости искушавао Јова. Истовремено се сматрају недостојнијим од њега, са мање наде у Божју милост („Али је ипак Јов био праведан, кога и Господ сам послуша правде његове ради”). ${ }^{8}$

3.

Доментијан изграђује јунака у потпуности окренутог духовном свету. Сава има врло активну улогу у српској цркви (њен је црквени поглавар, први по реду) али и држави; он је и законодавац (зборник црквених и грађанских закона), творац прописа о животу у најзначајнијим манастирима и ћелијама, итд. После смрти проглашен је за светитеља. Логично је очекивање да ће пишчев избор библијских јунака који ће му бити мерила за одређене особине и идеале бити другачији. Већ учињене опсервације о особеностима његовог књижевно-уметничког поступка, такође усмеравају ка закључку да се он на посебан начин односио и према библијским паралелама.

Сам попис имена библијских јунака са којима је вршена идентификација (узимани су у обзир само они са којима је Сава поређен), изненађује нас тиме што није предуг; ради се, међутим, о пробраним најзначајнијим личностима. ${ }^{9}$ По редоследу појављивања у делу то су: Исак, старозаветни патријарх (син Аврама и Саре), Јован Крститель, истакнута личност на размеђу Старог и Новог завета, аскета и проповедник, пророк, Христов

7 Ст. Првовенчани, Живот св. Симеона, стр. 72. Пророк Илија издао је, за време цара Агава (874-853 пре н.е.) наређење да се побију идолопоклонички свештеници (о томе Прва књига о царевима, гл. 18, нарочито стих 40). И за јеретике који се појављују у Немањино време Стефан каже да се клањају идолима. Отуда је Немања и могао бити упоређен са Илијом који је прогонио идолопоклонство.

8 Исто, стр. 76.

9 Доментијан, Живот светог Саве. У књизи: Живот светог Симеуна и свеmога Саве. Написао Доментијан. На свијет издао Ђ. Даничић, Београд, 1865, стр. 118-345 (даље: Доментијан: Живот св. Саве). 
Претеча, Аврам, по Библији праотац јеврејског народа, Јосиф, старозаветни патријарх (син Јакова и Рахеле), Авељ, син Адама и Еве, Мојсије, вођа јеврејског народа у избављењу из египатског ропства, верски вођа, први законодавац, апостол Петар, Христов ученик, Јаков, патријарх, Илија, пророк, Исаија, један од четворице великих пророка, и др.

Писац у принципу вишекратно користи паралелу са истим јунаком; поводи су, углавном, различити. По интензитету употребе и по значају који имају за конципирање лика главног јунака најзанимљивије су две - паралеле са Јованом Крститељем и паралела са Мојсијем. Принципи њиховог изграђивања унеколико су различити. Овом приликом бавићемо се првом паралелом.

4.

Паралела између Саве и Јована Крститеља успоставља се од самог почетка дела. Обрађујући мотив рођења јунака, писац његове родитеље упоређује са значајним библијским праведницима, који су у старости добили дете од Бога. Међу њима су и Захарије и Јелисавета (о њима у Јеванђељу по Луки, глава 1), чији је син Јован Крститељ. ${ }^{10}$ Да му је до помена Јована нарочито стало, Доментијан показује тиме што за њега каже: богосветла зрака, који проповеда истинито суние света, Христа Бога нашега. ${ }^{11}$ Ово место, формално гледајући, не даје повода за закључак да писац у овом тренутку пореди Саву са Јованом Крститељем.

Правом упоређивању приступа у другом поглављу, у моменту када говори о Растковом бекству у Свету Гору. ${ }^{12}$ Божји благослов за ово задобија тиме што је од младости заволео пустињски живот, угледајући се на Јована Крститеља, Христовог Претечу. Цитатом из Јеванђељь по Луки који се уграђује (Лк 1,80), документује се тврдња о Јовановом одласку у пустињу и истиче став да је он у њој остао „до дана јављања свога ка Израиљу (н тог высть до дьнє ґавлєннга своюго кь Нсранлю). ${ }^{13}$ Задржавајући се потом на Савином бављењу у пустињи, тј. у Светој Гори, што овај цитат стварно омогућава, истиче смисао његовог боравка али и велику пред-

10 Доментијан, Живот св. Саве, стр. 119.

11 „Такожає н Zахарне н Юелнсаветы Послоүшавь да ниа прнжнтн Крьстнтелю Ноана, вогосвьтлоүю zароү, нстнньною саьньце мнровн проповЊАающа, Хрнста Бога нашєГо" - Доментијан, Живот св. Саве, 119/18-20.

12 Друго поглавље је на стр. 123/22-139/15. Поменуто место налази се на $123 / 30-124 / 7$.

13 Доментијан, Живот св. Саве, 124/1-2. 
ност над Јованом, која проистиче из чињенице да над њим бди и о њему водИ рачуна сам Христос: „єєГО Же самь АюБьвн рачнтель Н волнтель МндостН

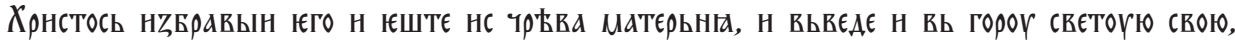

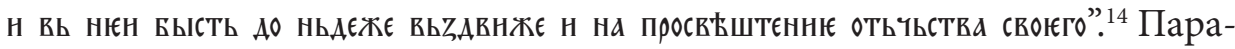
лела открива да је Јован био проповедник и крститељ а да је Сава постао духовни поглавар читаве једне државе. Доментијан истиче чињеницу изабраности када је у питању Сава, а занемарује да је Јован по Божјој (Јеховиној) вољи рођен. ${ }^{15}$ За Савин лик ова је паралела важна стога што открива да је Савин боравак у Светој Гори, о коме ће Доментијан тек говорити, заправо припрема за његову највишу, архиепископску дужност.

Наредна паралела такође је у склопу другог поглавља: смештена је непосредно иза одељка у коме се говори о великој жалости на Немањином двору (и у читавој држави) после вести о Растковом монашењу. Сликајући ново стање духа у српској држави које је наступило као резултат позитивног дејства Растковог подвига („оть толь нскра Божнга вьжежє

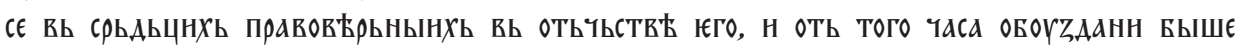
вьсн страхомь Божнємь"), писац довршава паралелу између Немање и Ане и Захарија и Јелисавете. ${ }^{16}$ У циљу истицања важности коју Јован Крститељ има за своје родитеље и још више ради општег сагледавања његовог значаја, наведен је у целини исказ из Јеванђељь по Луки 1,6; то су заправо речи арханђела Гаврила којим је наговештено Јованово рођење и наглашен основни смисао његовог живота: „БоүАєТь Б0, рєчє, тєББ радость

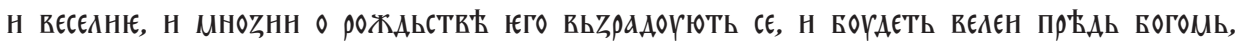

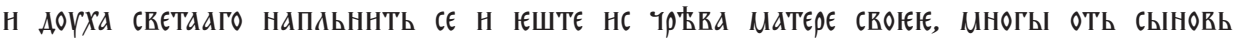

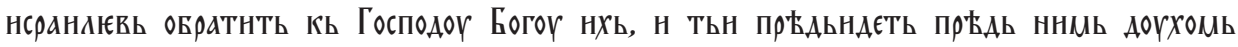

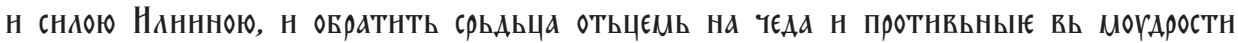
правєдьнынхь, оүготоватн господевн людн сьврьшєны". ${ }^{17}$ Јован се овде изједначава са очекиваним Илијом пророком. Исказ очигледно има карактер пророчанства; ово његово својство основни је разлог за његово коришћење; на такав закључак упућује део о Сави који је њему аналоган. Доментијан ту сагледава целокупни значај свога јунака; он наглашава Савине сродности са Крститељем („такождє н о сєГо юношн мноZнн о рождьствБ єєГо вь弓радовашє

\section{4 Исто, стр. 124/3-7.}

15 Види прво поглавље Јеванђеља по Луки, нарочито стихове 5-10. Све библијске текстове наводимо према књизи: Свето Писмо Старога и Новога Завјеma. Превео Стари Завјет Ђ. Даничић. Нови Завјет превео Вук Ст. Караџић. Издање Британског и иностраног Библијског друштва. Београд 1965. Јеванђеле по Луки је на стр. 54-87 (у другом делу књиге где је Нови завет).

${ }_{16}$ Доментијан, Живот св. Саве, 130/15-17.

17 Исто, стр. 130/26-131/2. 


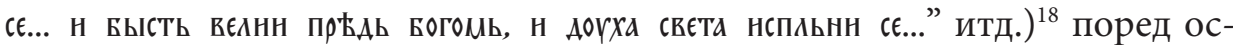
талог и у погледу идентификације са очекиваним пророком Илијом. О Сави се, међутим, говори шире, садржајније и конкретније. Спомиње се његово добро васпитање, конкретне заслуге на верском плану. Нарочито се апострофира ктиторска активност, што подразумева и активности везане за оформљење монашких заједница, итд. Доментијан никако не запоставља Савину улогу у утирању пута ка Светој Гори, где се овај светитељ такође огледао у зидању манастира и других објеката. Најзад, споменута су његова путовања у Свете Земље, чиме је утрт пут за касније српске ходочаснике. О Сави се чак говори као о већ умрлом светитељу. ${ }^{19}$

Обимом приповедања о Сави, презентираним садржајем и подацима, Доментијан постиже утисак о великој његовој предности над Јованом Крститељем. Занимљиво је да у Јеванђељу по Луки, којим се наш писац користио, постоји наизменично казивање о Јовану и Христу; фрагменти посвећени Христу обимнији су и поседују знатно више детаља.

Нова паралела остварује се у VI поглављу, на месту где започиње опис Савиног и Симеоновог подвизавања у тек завршеном Хиландару. ${ }^{20}$ Говорећи о њиховој великој љубави према Христу, писац уводи примере библијских јунака чија је љубав према Богу (не може бити Христ) изузетна: „нстнною Хрнста вьдлюБнвьша топлою АюБовню авельскою н вБрою авраамьскою,

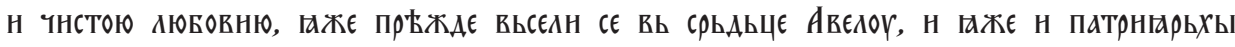

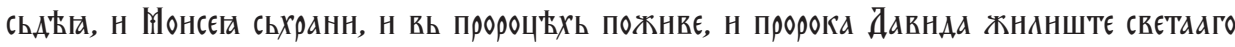
доүха сьтворн, н Нодна оүкрьпн”. ${ }^{21}$ Дакле, пример са Јованом Крститељем није нарочито издвојен а паралела се не тиче само Саве већ и његовог оца Симеона.

Доментијан не користи погодну могућност да учини паралелу у моменту када представља Савино похођење родне куће Јованове и пустиње у којој је проповедао. Очигледно је да у том раздобљу јунаковог живота историју Јована Крститеља не сматра актуелном за свога јунака.

Постоји и једно пост-поређење Саве са Јованом. Оно се даје након описа великог чуда на Савином гробу у Трнову и потиче од самога пи-

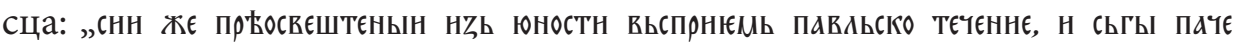

18 Исто, стр. 131/3-8.

19 Исто, стр. 131/4-132/2.

20 Шесто поглавље је на стр. 164/23-170/16. Опис Савиног и Симеоновог подвизавања почиње на 165/17.

${ }^{21}$ Доментијан, Живот св. Саве, стр. 165/24-29. 


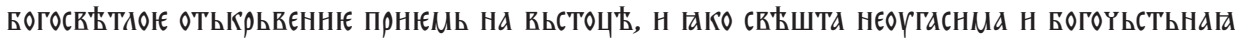

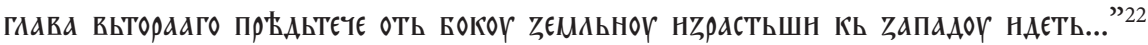

5.

1) Пажљивим читањем првог поглавља Јеванђељь по Луки и истовременим загледањем у прво поглавље Живота светог Саве, где осим назнаке паралеле других поређења нема, открива се постојање врло сродних места у ова два текста. За Саву се у његовој биографији каже да је добро изникли изданак од доброга корена у коме његови родитељи примају богосветлу радост; у Јеванђељу арханђел Гаврило, проричући о Јовановом рођењу, наглашава да ће он бити радост и веселье родитељима (они су стари и немају децу). ${ }^{23}$ Радост као основни израз родитељске осећајности према сину, али и као божанску, надстварну категорију, истиче Доментијан на другом месту у овом поглављу - упореди: вєлнког радость вьсєГда

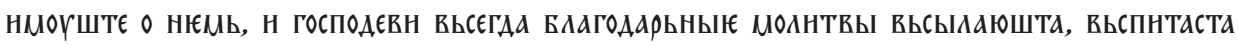

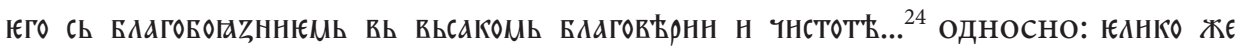

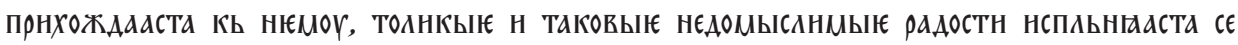

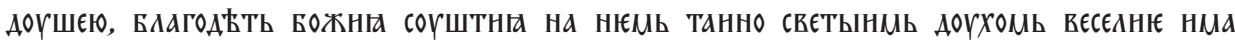

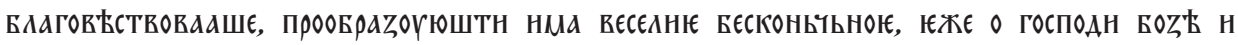

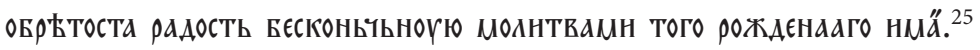

2) Са Доментијановом тврдњом да су Немања и Ана рођењем детета „ваистину примили извештење од Светога Духа, да им би дарован

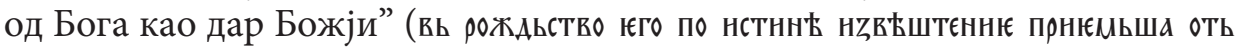
светаго доүха, ғако Аарь Божнн Ааровань нма Бысть оть Бога) ${ }^{26}$, кореспондира место из јеванђељског текста, где Захарије, путем Божјег анђела, добија вест о томе да ће добити сина. ${ }^{27}$

3) Приповедајући о посетама Немање и Ане сину, писац истиче њихову задивљеност и бригу, дефинисану питањем: „чьто оүБо БоүАєть отьрочє сніє вогомь посьданою нама”) ${ }^{28}$; на сродан начин: „Шта ће бити из овога дјетета?", питају се, о Јовану, суседи, родбина, али и многи у Горњој Јудеји. ${ }^{29}$

\footnotetext{
${ }_{22}$ Исто, стр. 342/13-18.

23 Јеванђеље по Луки, глава 1, стих 14.

24 Доментијан, Живот св. Саве, 120/12-15.

${ }_{25}$ Исто, стр. 120/24-30.

${ }_{26}$ Исто, стр. 120/10-12.

27 Јеванђеље по Луки, 1,11-17.

28 Доментијан, Живот св. Саве, стр. 120/22-23.

${ }_{29}$ Јеванђеле по Луки, 1,66.
} 
Повод је додуше другачији, чудо које се догодило у моменту када је детиње име на таблици исписао његов отац (руководио се божјим налогом).

4) Једно место из првог поглавља Јеванђеља по Луки нема своју паралелу у тексту првог поглавља Живота светог Саве, већ знатно касније у том делу. Ради се о Захаријином пророчанству о сину Јовану. У њему je, у општим цртама, представљена Јованова предстојећа мисија (= Лк, 1,76- 79). ${ }^{30}$ У Животу светог Саве постоји пророчанство његовог преминулог оца, светог Симеона (обично насловљено као: Симеоново јављање Сави у сну). ${ }^{31}$ Ту се утврђује целокупни садржај Савиног будућег живота, па је ово место идејно-мотивски предложак читавог наредног текста. Немањино пророчанство је текст знатно шири (и садржајнији) од текста Захаријиног пророчанства.

5) Исказ: преподобије и правда, тј. светост и правда, који је апострофиран код Луке (Захаријино пророчанство о сину, део где се исказује благослов Богу због похођења и избављења свога народа), када се говори о служењу Богу без страха, карактеристично је обележје Савиног начина служења Богу и помиње се много пута у делу. ${ }^{32}$

Ови примери показују да писац црте лика Јована Крститеља, оформљеног према Јеванђељу по Луки, усваја у већој мери но што се то може закључити праћењем назначених аналогија. Практично сви почетни мотиви (рођење, крштење, детињство, рана младост до момента одласка у Свету Гору), замишљени су и реализовани под видним утицајем овог библијског узора. Потпуна паралела, где су упоређени животи оба јунака у целости, могла је бити успостављена само уколико су за то већ биле учињене припреме. Тиме се може објаснити изразита сродност између Јеванђеља и Живота светог Саве у почетним мотивима, чињеница која на први поглед измиче пажњи јер је писац декларативно не истиче.

30 Ово место гласи: „И ти, дијете, назваћеш се пророк највишега: јер ћеш ићи напријед пред лицем Господњијем да му приправиш пут $(=1,76)$; Да даш разум спасенија народу његову за опроштење гријеха њиховијех $(=1,77)$; По дубокој милости Бога нашега, по којој нас је походио исток с висине $(=1,78)$; Да обасјаш оне који сједе у тами и у сјену смртноме; да упутиш ноге наше на пут мира $(=1,79)^{\prime}$.

31 Доментијан, Живот св. Саве, стр. 176/11-178/2.

32 И сам Сава, у својој молитви Богу, наглашава жељу да њему служи преподобијем и правдом („ПфБПодовнєщь н Правьдою сьПодоБн Мє вьсє дьнн жнвота МоюГо

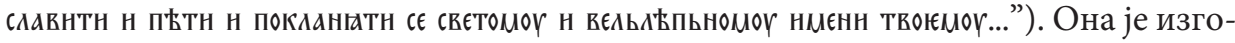
ворена у моменту када, дошавши за празник у Ватопед, настоји да и сам постане житељ овог манастира (Доментијан, Живот св. Саве, стр. 128/13-15). 
Изведена анализа потврђује почетна очекивања - да библијске паралеле имају посебан значај и функцију у грађењу Савиног лика, па и шире. Паралела Сава - Јован Крститељ доминантна је у првом делу житија и утиче на употпуњавање и рељефност јунаковог лика; одражава се и на природу мотива и фразеолошки план. Важна је и за идејну скицу потоњег садржаја. Будући да се ради о личности из Старог завета, Сава као хришћанин и Христов изабраник њу својим врлинама достиже и надмаша. Паралела има значаја и за атмосаферу дела, за поимање Доментијановог схватања поретка историје и света.

\section{Лиляна Юхас-Георгиевска}

\section{БИБЛЕЙСКИЕ ПАРАЛЛЕЛИ В ФУНКЦИИ ПОСТРОЕНИЯ ОБРАЗА ГЕРОЯ В „ЖИТИИ СВЯТОГО САВВЫ" ДОМЕНТИАНА}

Резюме

Произведение Житие святого Саввы иеромонаха Доментиана (оно закончено в 1242/43 или в 1253/54 гг.) отличается сложностью литературно-художественной структуры и богатством значений. Его отличительные признаки - это в высшей степени выраженная документальность и яркая символизация, с помощью которой реальный слой превращается в мифический и сверхреальный. Вполне понятно, что писатель с таким уклоном использует, весьма интенсивно и разнообразно, как раз библейские темы и мотивы как средство портретизации героя и восполнения всей атмосферы произведения и его значений.

Опора на Библию разнородна и постоянна; есть асоциации, цитаты (их 269, что не представляет окончательную цифру) и пр. В высказываниях писателя есть следы опоры на библейскую фразу, в частности на фразу, характерную для псалмов. На семантическом уровне описания путешествий Саввы в Святые места исключительно годны для дополнительного обогащения художественного видения. Соприкосновения с библейскими темами и фактами весьма интенсивны и многогранны, что требует серьезного и глубинного иследования структуры произведения.

Автор настоящей работы исследует функции библейских параллелей при построении образа главного героя. При этом он исходит из опыта предшественников Доментиана - Саввы Неманича и Стефана Первовенчанного. 
Указывается на факт, что Доментиан создает образ героя, полностью ориентированного на духовный мир и играющего весьма активную роль в сербской церкви и государстве. Констатируется, что сам перечень библейских героев, с которыми проводится идентификация, не объемист; однако, речь идет об отобранных значительных личностях.

Считая, что при создании образа главного героя самыми интересными были параллели Савва - Иоанн Креститель и Савва - Моисей, автор уделяет внимание первой. Проводя анализ, автор констатирует, что она является доминантной в первой части жития: она также оказывает влияние на восполнение и рельефность образа героя, на природу мотива и фразеологический план. Эта параллель имеет также большое значение для атмосферы произведения и для понимания доментиановского восприятия истории и мира. Савва своими достоинствами достигает и превышает Иоанна Крестителя; этот факт не необычен, так как он, будучи христианином, принадлежит Новому завету, в то время как Иоанн - ветхозаветная личность. Особо важно также то, что Савва избранник Христа, что Христос неустанно заботится о нем; будучи таким, он играет важную роль и имеет особое значение для своего народа. 